\title{
Present Status, Abundance and Threats of Fish Diversity on Ramsar Site (East Kolkata Wetlands) of West Bengal, India
}

\author{
Brajendu Kumar ${ }^{1}$, Satendra Kumar ${ }^{2}$, Auroshree Biswal ${ }^{3}$, Arpita Dey ${ }^{4}$, \\ Jyotismita Thakuria $^{5}$, Ajmal Hussan ${ }^{6}$, Arunjyoti Baruah ${ }^{7}$, Uday Kumar Udit ${ }^{\text {** }}$, \\ Prem Kumar Meher ${ }^{7}$ and Dilip Kumar $\operatorname{Singh}^{8}$ \\ ${ }^{1}$ Krishi Vigyan Kendra, Koshi College Khagaria-851205, India \\ ${ }^{2}$ KrishiVigyan Kendra (JNKVV), Dindori-481880, India \\ ${ }^{3}$ State Fisheries Dept. DFO, Kausalyaganga, Khorda 751002, India \\ ${ }^{4}$ Department of Zoology, University of North Bengal, Siliguri- 734 013, India \\ ${ }^{5}$ Live stock Research Station AAU-781127, India \\ ${ }^{6}$ ICAR-CIFA, Rahara Fish Farm, PO: Rahara, Kolkata-700118, India \\ ${ }^{7}$ ICAR-CIFA, Bhubaneswar-751002, India \\ ${ }^{8}$ ICAR-CIFE Centre Kolkata, West Bengal-700 091, India \\ *Corresponding author
}

\begin{tabular}{|c|}
\hline Keywords \\
\hline $\begin{array}{l}\text { Fish diversity, Ramsar } \\
\text { site, East Kolkata } \\
\text { Wetlands, threats and } \\
\text { Conservation status }\end{array}$ \\
\hline Article Info \\
\hline $\begin{array}{l}\text { Accepted: } \\
\text { 26 June } 2018 \\
\text { Available Online: } \\
\text { 10 July } 2018\end{array}$ \\
\hline
\end{tabular}

\section{A B S T R A C T}

The present study was conducted in the water bodies of East Kolkata Wetlands to generate a primary database on fish diversity of West Bengal, India. 71 indigenous fish species belonging to 27 families were identified. The family Cyprinidae represented the largest diversity accommodating 14 genera and 23 species. According to IUCN (International Union for Conservation of Nature) and CAMP (Conservation Assessment and Management Plan), the conservation status of the fishes are listed as 1 (1\%) species as Critically Endangered, 4(6\%) species as Endangered, $16(22 \%)$ species as Vulnerable, 21 (30\%) species as at Lower Risk Near Threatened, 21 (30\%) species as Lower Risk Least Concerned, 1(1\%) species as Data Deficient and 7 (10\%) species as Not Evaluated. About 59\% fish species are near threats, vulnerable and endangered in this region. Among the fish diversity of East Kolkata Wetlands58 species were indigenous species and 13 species were exotic. It is concluded, that anthropogenic pressure arising out of alterations of wetland habitats to agricultural lands, habitat destruction, over exploitation, wanton destruction, aquatic pollution, disease, exotic species introduce and overall lack of awareness of biodiversity importance, absence of proper policy are contributing much to such alarming vulnerability of the rich fish diversity in their natural habitat. Awareness programmes amongst the fisherman, strict ban on dividing of big-water bodies into fragmented small ponds, repeated drying of maturation pond, loss of natural breeding ground for endangered species, use of insecticides and pesticides in ponds to control unwanted species. 


\section{Introduction}

East Kolkata Wetlands, a complex of natural and man-made wetlands lying east of the city of Kolkata, is the only Ramsar site in West Bengal. East Kolkata Wetlands is the largest wastewater wetlands among the 26Ramsar Sites (Ramsar, 2013) in India. It provides livelihood support to a large, economically underprivileged population of around 27,000 families which depend upon the various wetland products, primarily fish and vegetables for sustenance (National Wetland Atlas, 2010). The wetland system currently produces over 15,000 MT per annum from its 264 functioning aquaculture ponds, locally called bheries. Additionally, nearly 150 MT of vegetables are produced daily by subsistence farmers. Based on its immense ecological and socio cultural importance, East Kolkata Wetlands was designated a "Wetland of International Importance" under the Ramsar Convention on August 19, 2002 (Ramsar 2007).The East Kolkata Wetlands is located in such a low-lying region. It was once covered with salt-water marshes. Those salt-water marshes were between the River Hooghly to the west and the River Bidyadhari, a tidal channel, to the East. The mouths of some of the streams opened into the Bay of Bengal and were influenced by tidal action, which accounted for the tides and salinity of these salt-water lakes. These lakes were actually the spill-reservoirs of the tidal channel Bidyadhari which opened into the Bay of Bengal through the river Matla. At present the East Kolkata Wetlands encompasses 264 operating bheries (Shallow fresh or brackish water bodies for pisciculture). Of the total area of 12,500 ha, approximately $45.93 \%$ comprises water bodies and $38.92 \%$ is agricultural land. The remaining portion is occupied by urban and rural settlements $(10.42 \%)$ and sites for garbage disposal (4.73\%).East Kolkata Wetlands with rich biodiversity is under immediate threat of species extinction and habitat destruction due to anthropogenic factors.

The few contributors on fish diversity of East Kolkata Wetlands of West Bengal were De et al., (1989), Wetlands International (2008), Mahapatra and Lakra (2014) and Mahapatra et al., (2015). Since the existing literatures do not give present status, abundance and threats of fish diversity of East Kolkata Wetlands. The present study, therefore, is aimed at to update the ichthyofaunal diversity in the East Kolkata Wetlands and to get a database of fish species.

\section{Materials and Methods}

The study was conducted in the ponds of East Kolkata Wetlands. The work was surveyed over a period of one year (September 2016 to August 2017) at monthly interval. Fishes were collected from different sites with the help of fishermen using different types of nets namely, gill nets, cast nets, dip nets, drag nets. The harvested fishes are then preserved in 10 \%formaldehyde solution Jayaram (1999). Fish photographs were taken from fresh samples by camera (Nikon, CoolpixL24) and were identified following their general body form, morphometric and meristic characteristics according to Talwar and Jhingran (1991), Jayaram (1999), and Vishwanath et al., (2011). Conservation status of fish isgiven as per Conservation Assessment and Management Plan (CAMP, 1998) and International Union for Conservation of Nature (IUCN, 2016).

\section{Results and Discussion}

Seventy one fish species belonging to 27 families were collected and identified from the ponds of East Kolkata Wetlands. The familywise interpretation (Fig. 1) revealed Cyprinidae as the largest family accommodating 14 genera and 23 species. The 
genus Puntius, ranked first among the genera with its numerical strength of 6 species. Family Bagridae with 7 species. Mastacembelidae, Channidae and Loricariidae family represented 3 species. Ambassidae, Belontiidae, Mugilidae, Notopteridae, Pangasiidae, Siluridae, Schilbeidae, Synbranchidae, Cichilidae and Clariidae showed 2 members from each family. Belonidae, Anabantidae, Aplocheilidae, Cobitidae, Badidae, Chacidae, Gobiidae, Heteropneustidae, Nandidae, Tetradontidae, Latidae and Serrasalmidae represented single member from each.

Data of above showed that 11 species such as Puntius ticto, Puntius sophore, Mystus tengra, Channa punctatus, Channagachua, Channa marulius, Mystusvittatus, Heteropneus tesfossilis, Clarius batrachus, Talapia mossambica and Puntius javanicus were abundant in the East Kolkata Wetlands (Fig. $1)$.

Food fishes were dominant over the ornamental fishes. 34 species have food value and 22 species the ornamental value. 15 species have both value ornamental as well as food (Table 1). An insight into the conservation status of fishes as per CAMP (1998) and IUCN (2010) revealed, under the different categories, One species was critically 'Endangered' (CEN), 21 species are under 'Low Risk Least Concern' (LRlc), 21 species were 'Low Risk Near Threatened' (LRnt), 16 species were 'Vulnerable' (VU), 4 species were 'Endangered' (EN), one species were 'Data Deficient' (DD) and 7 fish species were 'Not Evaluated' (NE) category and (Fig. 2).

All the three types of feeding habits of fishes like carnivorous, omnivorous and herbivorous were available in this region. Forty species of fishes were carnivorous, 29 species were herbivorous and 11 species were omnivorous fish (Fig. 3).
Few authors reported fish diversity of different districts of West Bengal. Menon (1962) reported 218 species of fish from whole Himalayas, Wetlands International (2008) reported 45 fish species from East Kolkata Wetland, Roshith et al., (2012) reported 155 fish species from the tidal freshwater zone of the Hooghly estuary. Sanyal et al., (2012) reported 207 species from Sundarban. Mahapatra and Lakra (2012) reported 50 species from East Kolkata Wetland, among the 50 species 17 are cultured and 33 are wild species. Basu et al., (2012) reported 70 Indigenous ornamental fishes of west Bengal. Patraand Saha (2013) recorded 46 species from Damodar River, Burdwan district.

Mahapatra et al., (2015) reported 190 fish species from West Bengal. Acharjee and Barat (2013) reported 65 species from Teestariver, Mahapatra and Lakra (2014) reported 41 ornamental fish from East Kolkata Wetland. Mahapatra et al., (2015) reported 190 native, Dey et al., (2015a) reported 138 species from Kaljani river of Cooch Behar, Dey et al., (2015b) reported 141 species from rivers of East Himalayan region. The present study showed that 71 species were available in the study area, 58 were indigenous species and 13 were exotic species.

East Kolkata wetlands, an ecologically important Ramsar site, located on the periurban interface of Kolkata City have been under continuous pressures of conversion for settlements and agriculture. These wetlands which are famous for fishery activities receive pollutants like heavy metal, oil, grease etc. through effluent of different industries like tannery, electroplating, plastic and dye industries of surroundings and alter the ecosystem. The rich fish germ plasma resources of East Kolkata wetlands have been suffering from various serious anthro-graphics stress leading to not only reduced abundance but even touching the genetic threshold. 
Table.1 Fish diversity of different water bodies of East Kolkata Wetlands

\begin{tabular}{|c|c|c|c|c|c|}
\hline $\begin{array}{l}\text { Sl. } \\
\text { No. }\end{array}$ & Scientific name & Family & $\begin{array}{c}\text { Conser } \\
\text {-vation } \\
\text { status }\end{array}$ & $\begin{array}{l}\text { Econ- } \\
\text { omic } \\
\text { value }\end{array}$ & $\begin{array}{l}\text { Food } \\
\text { habit }\end{array}$ \\
\hline 1 & Anabas testudineus(Bloch) & Anabantidae & VU & $\mathrm{Fd}$ & $\mathrm{C}$ \\
\hline 2 & Pseudambassisranga(Hamilton-Buchanan) & Ambassidae & LRnt & Or & $\mathrm{C}$ \\
\hline 3 & Chandanama(Hamilton-Buchanan) & Ambassidae & LRnt & Or & $\mathrm{C}$ \\
\hline 4 & Aplocheiluspanchax(Hamilton) & Aplocheilidae & LRlc & Or & $\mathrm{O}$ \\
\hline 5 & Mystusbleekeri(Day) & Bagridae & VU & $\mathrm{Fd} / \mathrm{Or}$ & $\mathrm{C}$ \\
\hline 6 & Mystustengara(Hamilton) & Bagridae & LRlc & $\mathrm{Fd} / \mathrm{Or}$ & $\mathrm{C}$ \\
\hline 7 & Mystusgulio(Hamilton) & Bagridae & LRlc & $\mathrm{Fd} / \mathrm{Or}$ & $\mathrm{C}$ \\
\hline 8 & Mystusvittatus(Bloch) & Bagridae & VU & $\mathrm{Fd} / \mathrm{Or}$ & $\mathrm{C}$ \\
\hline 9 & Sperataaor(Hamilton) & Bagridae & VU & $\mathrm{Fd}$ & $\mathrm{C}$ \\
\hline 10 & Batasioaffinis(Blyth) & Bagridae & LRnt & $\mathrm{Fd} / \mathrm{Or}$ & $\mathrm{C}$ \\
\hline 11 & Rita rita(Hamilton -Buchanan) & Bagridae & VU & $\mathrm{Fd} / \mathrm{Or}$ & $\mathrm{C}$ \\
\hline 12 & Xenentodoncancila(Hamilton) & Belonidae & LRlc & Or & $\mathrm{C}$ \\
\hline 13 & Badisbadis(Hamilton) & Badidae & LRlc & Or & $\mathrm{C}$ \\
\hline 14 & Colisafasciatus (Schneider) & Belontiidae & LRnt & Or & $\mathrm{C}$ \\
\hline 15 & Colisalalia(Hamilton -Buchanan) & Belontiidae & LRlc & Or & $\mathrm{C}$ \\
\hline 16 & Chacachaca(Hamilton-Buchanan) & Chacidae & EN & Or & $\mathrm{C}$ \\
\hline 17 & Channastriata(Bloch) & Channidae & LRlc & $\mathrm{Fd}$ & $\mathrm{C}$ \\
\hline 18 & Channagachua(Hamilton) & Channidae & LRlc & $\mathrm{Fd} / \mathrm{Or}$ & $\mathrm{C}$ \\
\hline 19 & Channamarulius(Hamilton) & Channidae & LRnt & $\mathrm{Fd}$ & $\mathrm{C}$ \\
\hline 20 & Amblypharyngodonmola(Hamilton-Buchanan) & Cyprinidae & LRlc & $\mathrm{Fd} / \mathrm{Or}$ & $\mathrm{H}$ \\
\hline 21 & Cirrhinusreba(Hamilton) & Cyprinidae & VU & $\mathrm{Fd}$ & $\mathrm{O}$ \\
\hline 22 & Raiamas bola (Hamilton) & Cyprinidae & VU & $\mathrm{Fd} / \mathrm{Or}$ & $\mathrm{C}$ \\
\hline 23 & Salmophasiabacaila(Hamilton) & Cyprinidae & LRnt & $\mathrm{Fd} / \mathrm{Or}$ & $\mathrm{C}$ \\
\hline 24 & Labeorohita(Hamilton -Buchanan) & Cyprinidae & LRnt & $\mathrm{Fd}$ & $\mathrm{H}$ \\
\hline 25 & Labeocalbasu(Hamilton) & Cyprinidae & LRlc & $\mathrm{Fd}$ & $\mathrm{H}$ \\
\hline 26 & Labeobata(Hamilton) & Cyprinidae & LRnt & $\mathrm{Fd}$ & $\mathrm{H}$ \\
\hline 27 & Catlacatla(Hamilton-Buchanan) & Cyprinidae & VU & $\mathrm{Fd}$ & $\mathrm{H}$ \\
\hline 28 & Cirrhinusmrigala(Hamilton-Buchanan) & Cyprinidae & LRnt & $\mathrm{Fd}$ & $\mathrm{O}$ \\
\hline 29 & Puntiuschola(Hamilton-Buchanan) & Cyprinidae & LRlc & Or & $\mathrm{C}$ \\
\hline 30 & Puntiusconchonius(Hamilton) & Cyprinidae & LRlc & Or & $\mathrm{C}$ \\
\hline 31 & Puntiussarana(Hamilton) & Cyprinidae & VU & $\mathrm{Fd}$ & $\mathrm{C}$ \\
\hline 32 & Puntiussophore(Hamilton) & Cyprinidae & LRnt & Or & $\mathrm{C}$ \\
\hline 33 & Puntiusterio(Hamilton) & Cyprinidae & LRnt & Or & $\mathrm{C}$ \\
\hline 34 & Puntiusticto(Hamilton) & Cyprinidae & LRnt & Or & $\mathrm{C}$ \\
\hline 35 & Esomusdanricus(Hamilton-Buchanan) & Cyprinidae & LRlc & Or & $\mathrm{O}$ \\
\hline 36 & Daniorerio(Hamilton) & Cyprinidae & LRlc & Or & $\mathrm{O}$ \\
\hline
\end{tabular}




\begin{tabular}{|c|c|c|c|c|c|}
\hline 37 & Laubucalaubuca(Hamilton) & Cyprinidae & LRlc & Or & $\mathrm{O}$ \\
\hline 38 & Lepidocephalusguntea(Hamilton) & Cobitidae & LRlc & Or & $\mathrm{C}$ \\
\hline 39 & Glossogobiusgiuris(Hamilton-Buchanan) & Gobiidae & LRnt & $\mathrm{Fd}$ & $\mathrm{C}$ \\
\hline 40 & Heteropneustesfossilis(Bloch) & Heteropneustidae & VU & $\mathrm{Fd}$ & $\mathrm{O}$ \\
\hline 41 & Clariusbatrachus(Linnaeaus) & Clariidae & VU & $\mathrm{Fd}$ & $\mathrm{C}$ \\
\hline 42 & Rhinomugilcorsula(Hamilton) & Mugilidae & VU & $\mathrm{Fd} / \mathrm{Or}$ & $\mathrm{H}$ \\
\hline 43 & Macrognathusaral(Bloch and Schneider) & Mastacembelidae & LRnt & $\mathrm{Fd} / \mathrm{Or}$ & $\mathrm{C}$ \\
\hline 44 & Macrognathuspancalus(Hamilton) & Mastacembelidae & LRnt & $\mathrm{Fd} / \mathrm{Or}$ & $\mathrm{C}$ \\
\hline 45 & Mastacembelusarmatus(Lacepede) & Mastacembelidae & LRlc & $\mathrm{Fd} / \mathrm{Or}$ & $\mathrm{C}$ \\
\hline 46 & Nandusnandus(Hamilton-Buchanan) & Nandidae & LRnt & Or & $\mathrm{C}$ \\
\hline 47 & Notopterusnotopterus(Pallas) & Notopteridae & EN & $\mathrm{Fd}$ & $\mathrm{O}$ \\
\hline 48 & Notopteruschitala(Hamilton- Buchanan) & Notopteridae & EN & $\mathrm{Fd}$ & $\mathrm{C}$ \\
\hline 49 & Pangasiuspangasius(Hamilton-Buchanan) & Pangasiidae & CEN & $\mathrm{Fd}$ & $\mathrm{C}$ \\
\hline 50 & Ompokpabda(Hamilton) & Siluridae & $\mathrm{VU}$ & $\mathrm{Fd}$ & $\mathrm{C}$ \\
\hline 51 & Wallagoattu(Schneider) & Siluridae & VU & $\mathrm{Fd}$ & $\mathrm{C}$ \\
\hline 52 & Neotropiusatherinoides(Bloach) & Schilbeidae & LRlc & $\mathrm{Fd}$ & $\mathrm{C}$ \\
\hline 53 & Ailiacoila(Hamilton) & Schilbeidae & VU & $\mathrm{Fd}$ & $\mathrm{C}$ \\
\hline 54 & Amphipnouscuchia(Hamilton-Buchanan) & Synbranchidae & VU & $\mathrm{Fd}$ & $\mathrm{C}$ \\
\hline 55 & Ophisternonbengalense(McClelland) & Synbranchidae & LRlc & $\mathrm{Fd}$ & $\mathrm{C}$ \\
\hline 56 & Tetradoncutcutia(Hamilton-Buchanan) & Tetradontidae & LRnt & Or & $\mathrm{O}$ \\
\hline 57 & Liza parsia(Forsskal) & Mugilidae & DD & $\mathrm{Fd}$ & $\mathrm{C}$ \\
\hline 58 & Latescalcarifer(Bloch) & Latidae & $\mathrm{NE}$ & $\mathrm{Fd}$ & $\mathrm{C}$ \\
\hline 59 & Hурорhthalmichthysmolitrix(Valenciennes) & Cyprinidae & LRnt & $\mathrm{Fd}$ & $\mathrm{H}$ \\
\hline 60 & Cyprinuscarpio(Linnaeus) & Cyprinidae & LRnt & $\mathrm{Fd}$ & $\mathrm{O}$ \\
\hline 61 & Ctenopharyngodonidella(Valenciennes) & Cyprinidae & $\mathrm{NE}$ & $\mathrm{Fd}$ & $\mathrm{H}$ \\
\hline 62 & Hypophthalmichthysnobilis(Richardson) & Cyprinidae & LRnt & $\mathrm{Fd}$ & $\mathrm{O}$ \\
\hline 63 & Talapiamossambica(Peters) & Cichilidae & LRnt & $\mathrm{Fd}$ & $\mathrm{C}$ \\
\hline 64 & Oreochromisniloticus(Linnaeus) & Cichilidae & $\mathrm{NE}$ & $\mathrm{Fd}$ & $\mathrm{C}$ \\
\hline 65 & Piaractusbrachypomus(Pirapitinga) & Serrasalmidae & $\mathrm{NE}$ & $\mathrm{Fd}$ & $\mathrm{H}$ \\
\hline 66 & Clariasgariepinus(Burchell) & Claridae & LRlc & $\mathrm{Fd}$ & $\mathrm{C}$ \\
\hline 67 & Pangasianodonhypophthalmus(Sauvage) & Pangasiidae & EN & $\mathrm{Fd} / \mathrm{Or}$ & $\mathrm{C}$ \\
\hline 68 & Puntiusjavanicus(Bleeker) & Cyprinidae & LRlc & $\mathrm{Fd}$ & $\mathrm{C}$ \\
\hline 69 & Pterygoplichthysdisjunctivus(Weber) & Loricariidae & $\mathrm{NE}$ & Or & $\mathrm{H}$ \\
\hline 70 & $\begin{array}{l}\text { Pterygoplichthysanisitsi(Eigenmann } \\
\text { Kennedy) }\end{array}$ & Loricariidae & $\mathrm{NE}$ & Or & $\mathrm{H}$ \\
\hline 71 & Pterygoplichthysmultiradiatus(Hancock) & Loricariidae & $\mathrm{NE}$ & Or & $\mathrm{H}$ \\
\hline
\end{tabular}

Note: Feeding habit: $\mathrm{O}=$ Omnivorous, $\mathrm{C}=$ Carnivorous, $\mathrm{H}=$ Herbivorus, Economic importance: $\mathrm{Fd}=$ Food fish, Or= Ornamental fish. Conservation status: According to IUCN (2010) and CAMP (1998). DD= Data deficient, NE= Not evaluated, VU $=$ Vulnerable, $\mathrm{EN}=$ Endangered, $\mathrm{CEN}=$ critically endangered, LRnt=Lower risk near threatened, LRlc=lower risk least concern. 
Fig.1 Total family wise distribution of fish diversity East Kolkata Wetlands

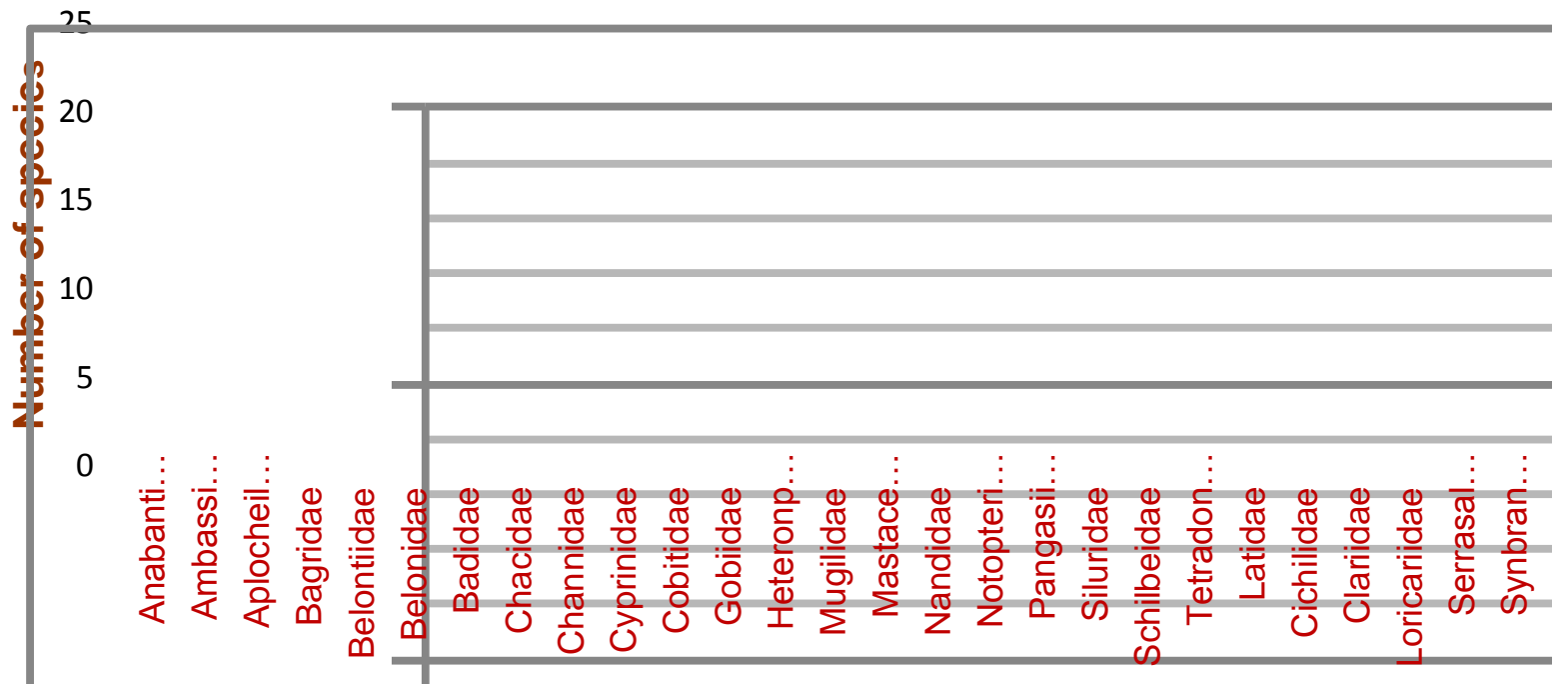

Fig.2 Bar diagram showing the present conservation status of fish in East Kolkata Wetlands

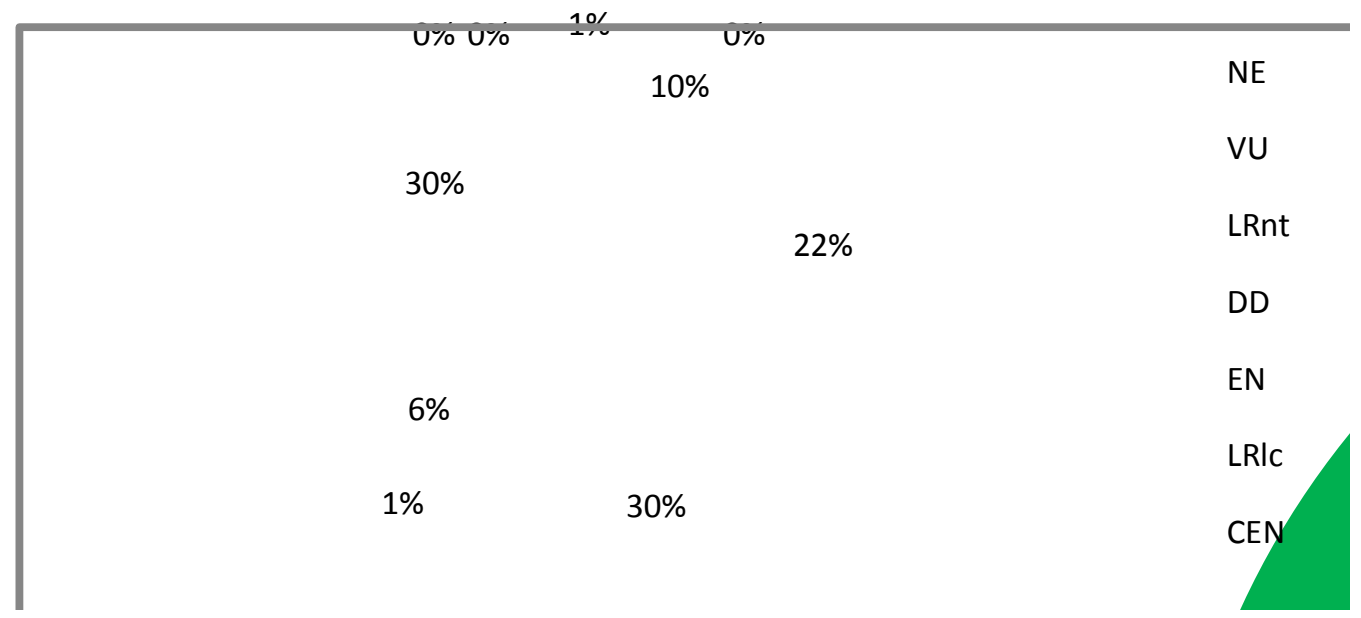

Fig.3 Bar diagram showing the numbers of available fish feeding habit of East Kolkata Wetlands

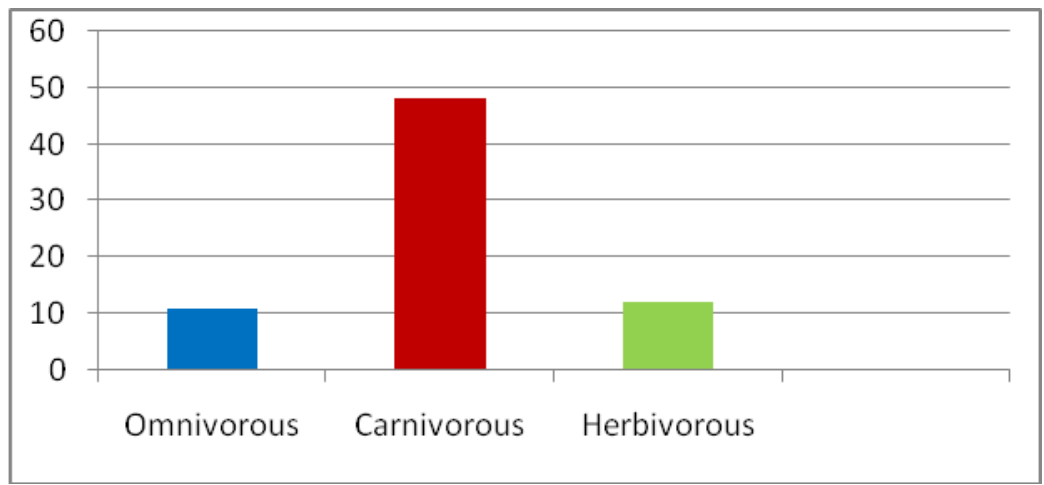


The stresses include intense encroachment stress from urban expansion, alterations of wetland habitats to agricultural lands, habitual destruction, over exploitation, wanton destruction, aquatic pollution, disease and exotic and overall lack of awareness of biodiversity importance, absence of proper policy.

Introduction of exotic fishes, as a part of aquaculture for commercial gains or accidental introduction of undesired exotic fishes are resulting loss of indigenous fish diversity in East Kolkata wetlands. Good populations of Pterygoplichthys, a widespread invasive fish species with strong ability to survive even in hypoxic condition, were recorded in EKW in recent time. Invasive Pterygoplichthys, being large and bewilderingly resilient bottom feeder species, may displace smaller or less aggressive benthic fishes and also may incidentally ingest eggs of native fishes while consuming the bottom periphyton (Hoover et al., 2004). The smaller sized indigenous fishes with comparatively short life spans, low fecundity, and limited resistance to hypoxia and desiccation, would not compete with the more competitive Pterygoplichthys sp. established in the ecosystems (Hoover et al., 2004) and thus chances of their displacement is high. Another alien fish species is Aristichthysnobilis (Bighead carp) which affected the population of Indian Major Carps. Over-exploitation of fishery resources due to its higher economic value has increased the vulnerability of the population in different ecosystems, Chitala chitala, Ompok pabda, Pangasius pangasius and so on in warm water (Mahapatra et al., 2015)

East Kolkata Wetland is a classical example of natural resources of the wetland system for fisheries and agriculture through ingenuity of local communities with their traditional knowledge. It is the largest ensemble of sewage for fish ponds in one place in the world. Anthropogenic activities are resulting in the loss of wetland biodiversity and ecosystem integrity. Indigenous fish fauna of this wetlands are being threatened due to several anthropogenic activities mainly introduction of exotic fish species, habitat degradation and pollution. Thus, awareness programmes amongst the fishers, strict ban on illegal monsoon fishing, uncontrolled introduction of exotic fishes, repeated drying of maturation pond and usage of proper mesh size nets should be involved. Besides, the protection of breeding grounds from agricultural run-offs and indiscriminate fishing of commercially important fish species should be established which would ultimately protect and conserve the endangered species. Adopting proper and balanced methodologies for enhancing fish diversity of East Kolkata Wetland without affecting socio-economic condition of East Kolkata Wetland beneficiaries is need of the hour to save this world's largest wastewater recycle region. Policy makers and implementing agencies also be educated about biodiversity importance for our world.

\section{References}

Acharjee M.L. and Barat S., 2013. Ichthyofaunal Diversity of Teesta River in Darjeeling Himalaya of West Bengal, India. Asian Journal of Experimental Biological Sciences, 4(1): 112-122.

Basu A., Dutta D., and Banerjee S., 2012.Indigenous ornamental fishes of West Bengal. Recent Research in Science and Technology, 4(11): 12-21.

CAMP, 1998.Conservation Assessment and Management Plan Workshops, (Ed) Sanjay Molur and Sally Walker. Published by Zoo Outreach organization. National Bureau of Fish Genetics Resources. Lucknow, India.

De M., Bhunia, S. and Sengupta, T., 1989. A Preliminary Account on Major Wetland Fauna of Calcutta and Surroundings. Ecology, 3 (9): 5-11.

Dey A., Nur R., Sarkar D. and Barat S., 2015a. Ichthyofauna Diversity of river Kaljani in Cooch Behar District of West Bengal, India. International Journal of Pure and Applied Bioscience, 3 (1): 247-256. 
Dey A., Sarkar K. and Barat S., 2015b. Evaluation of fish biodiversity in rivers of three districts of eastern Himalayan region for conservation and sustainability. International Journal of Applied Research, 1(9): 424-435

HooverJ. J., Killgore J. and Murphy C. E., 2004. Ecological Impacts of Suckermouth Catfishes (Loricariidae) in North America: A Conceptual Model. Aquatic Nuisance Species Research Program Bulletin, 14 (1): 2-3.

IUCN. 2010. Red List of Threatened Species. [http://www.iucnredlist.org/apps/redlist/se $\operatorname{arch}]$.

Jayaram K.C., 1999. The Freshwater Fishes of Indian Region. New Delhi: Narendra Publishing House.

Mahapatra B.K. and Lakra W.S., 2012. Indigenous Ornamental fish diversity of West Bengal: Conservation and management for sustainability. 23rd All India Congress of Zoology and National Conference on Conservation and Management of Faunal Resources at Guru Nanak College, Chennai.

Mahapatra B.K. and Lakra W.S., 2014. Ornamental Fishes of East Kolkata Wetland, West Bengal, India. International Journal of Scientific Research, 3 (12): 406-408.

Mahapatra B.K., Sarkar U.K., and Lakra W.S., 2015. A Review on Status, Potentials, Threats and Challenges of the Fish Biodiversity of West Bengal. Biodiversity, Bioprospecting and Development.

Menon A.G.K., 1962. A distributional list of fishes of the Himalayas. Journal of Zoological Society, India, 14: 23-32.
National Wetland Atlas, 2010. Ministry of Environment and Forests (MoEF), Government of India.

Patra B.C. and Saha M.K., 2013. Present Status of Ichthyofaunal diversity at Damodor River at Burdwan district, West Bengal, India. International Journal of Scientific and Research Publications, 3: 6.

Ramsar Secretariat, 2013. The List of Wetlands of International Importance. The Secretariat of the Convention on Wetlands, Gland, Switzerland.

Ramsar, 2007. Ramsar Sites Information Service. http://ramsar.wetlands.org.

Roshith C.M., Sharma A.P., Manna R.K., Satpathy B.B. and Bhaumik U., 2012. Ichthyofaunal diversity, assemblage structure and seasonal dynamics in thefreshwater tidal stretch of Hooghly estuary along the Gangetic delta. Publisher: Taylor and Francis, 16: 445453.

Sanyal A.K., Alfred J.R.B., Venkataraman K., Tiwari S.K. and Mitra S., 2012. Status of Biodiversity of West Bengal. ZSI.

Talwar P.K. and Jhingran A.G., 1991. Inland Fishes of India and Adjacent Countries. New Delhi: Oxford and IBH Co., Private Limited, 1158.

Vishwanath W., Mahanta P.C., Anganthoibi N. and Sarma D., 2011. Coldwater Fishes of India-An Atlas. Directorate of Cold water Fisheries Research (ICAR), Bhimtal, Uttarakhand, India.

Wetlands International, 2008. Management Plan for East Kolkata Wetlands. Final Report submitted to East Kolkata Wetlands Management Authority. Wetlands International -South Asia, New Delhi, India.

\section{How to cite this article:}

Brajendu Kumar, Satendra Kumar, Auroshree Biswal, Arpita Dey, Jyotismita Thakuria, Ajmal Hussan, Arunjyoti Baruah, Uday Kumar Udit, Prem Kumar Meher and Dilip Kumar Singh. 2018. Present Status, Abundance and Threats of Fish Diversity on Ramsar Site (East Kolkata Wetlands) of West Bengal, India. Int.J.Curr.Microbiol.App.Sci. 7(07): 4000-4007. doi: https://doi.org/10.20546/ijcmas.2018.707.466 